\title{
Particle export fluxes to the oxygen minimum zone of the eastern tropical North Atlantic
}

\author{
Anja Engel ${ }^{1}$, Hannes Wagner ${ }^{1}$, Frédéric A. C. Le Moigne ${ }^{1}$, and Samuel T. Wilson ${ }^{2}$ \\ ${ }^{1}$ GEOMAR Helmholtz Centre for Ocean Research Kiel, 24105 Kiel, Germany \\ ${ }^{2}$ Daniel K. Inouye Center for Microbial Oceanography: Research and Education, Department of Oceanography, \\ University of Hawaii, Honolulu, HI 96822, USA \\ Correspondence to: Anja Engel (aengel@geomar.de)
}

Received: 25 November 2016 - Discussion started: 28 November 2016

Revised: 6 March 2017 - Accepted: 12 March 2017 - Published: 5 April 2017

\begin{abstract}
In the ocean, sinking of particulate organic matter (POM) drives carbon export from the euphotic zone and supplies nutrition to mesopelagic communities, the feeding and degradation activities of which in turn lead to export flux attenuation. Oxygen $\left(\mathrm{O}_{2}\right)$ minimum zones (OMZs) with suboxic water layers $\left(<5 \mu \mathrm{mol} \mathrm{O}_{2} \mathrm{~kg}^{-1}\right)$ show a lower carbon flux attenuation compared to welloxygenated waters ( $>100 \mu \mathrm{mol} \mathrm{O}_{2} \mathrm{~kg}^{-1}$ ), supposedly due to reduced heterotrophic activity. This study focuses on sinking particle fluxes through hypoxic mesopelagic waters $\left(<60 \mu \mathrm{mol} \mathrm{O} \mathrm{kg}^{-1}\right)$; these represent $\sim 100$ times more ocean volume globally compared to suboxic waters, but they have less been studied. Particle export fluxes and attenuation coefficients were determined in the eastern tropical North Atlantic (ETNA) using two surface-tethered drifting sediment trap arrays with seven trapping depths located between 100 and $600 \mathrm{~m}$. Data on particulate matter fluxes were fitted to the normalized power function $F_{z}=F_{100}(z / 100)^{-b}$, with $F_{100}$ being the flux at a depth $(z)$ of $100 \mathrm{~m}$ and $b$ being the attenuation coefficient. Higher $b$ values suggest stronger flux attenuation and are influenced by factors such as faster degradation at higher temperatures. In this study, $b$ values of organic carbon fluxes varied between 0.74 and 0.80 and were in the intermediate range of previous reports, but lower than expected from seawater temperatures within the upper $500 \mathrm{~m}$. During this study, highest $b$ values were determined for fluxes of particulate hydrolyzable amino acids (PHAA), followed by particulate organic phosphorus (POP), nitrogen (PN), carbon (POC), chlorophyll $a(\mathrm{Chl} a)$ and transparent exopolymer particles (TEP), pointing to a sequential degradation of organic matter components during sinking. Our study sug-
\end{abstract}

gests that in addition to $\mathrm{O}_{2}$ concentration, organic matter composition co-determines transfer efficiency through the mesopelagic. The magnitude of future carbon export fluxes may therefore also depend on how organic matter quality in the surface ocean changes under influence of warming, acidification and enhanced stratification.

\section{Introduction}

The biological carbon pump, defined as the export of biologically fixed carbon dioxide $\left(\mathrm{CO}_{2}\right)$ from the surface to the deeper ocean mainly in the form of sinking particles (Volk and Hoffert, 1985), influences atmospheric $\mathrm{CO}_{2}$ concentration and affects ecosystem structure and elemental distributions in the ocean. The total amount of carbon export as well as the efficiency of the biological carbon pump, i.e., the ratio between export and primary production, are highly dynamic (Buesseler and Boyd, 2009; Lam et al., 2011). Changes in the efficiency of the biological carbon pump may have been responsible for past atmospheric $\mathrm{CO}_{2}$ variability between glacial-interglacial transition periods (Kohfeld and Ridgewell, 2009) and play a key role for future climate predictions (Heinze et al., 2015).

Most of the POM being exported below the surface mixed layer $(<200 \mathrm{~m}$ in general) is solubilized and remineralized within the mesopelagic layer, i.e., between depths of 200 and $1000 \mathrm{~m}$ (Bishop et al., 1978; Suess, 1980). The shallower the carbon remineralization depth, the more likely $\mathrm{CO}_{2}$ is to exchange with the atmosphere and hence drive a shorter carbon storage time in the ocean (Volk and Hoffert, 1985; Kwon et 
al., 2009). The factors driving export flux attenuation in the mesopelagic therefore have a large influence on $\mathrm{CO}_{2}$ sequestration in the ocean. The vertical profile of sinking particulate organic carbon (POC) flux has often been described by a normalized power function: $F_{z}=F_{100}(z / 100)^{-b}$, where $F_{z}$ is the particle flux as a function of depth $z, F_{100}$ is the flux at $100 \mathrm{~m}$ depth and $b$ is the flux attenuation coefficient (Martin et al., 1987; hereafter M87). The authors of the M87 study derived an "open ocean composite" for POC export fluxes from North Pacific data with a $F_{100}=50.3 \mathrm{mg} \mathrm{m}^{-2} \mathrm{~d}^{-1}$ and $b=0.86$. However, strong regional variations of both total export POC fluxes and $b$ values are observed (Martin et al., 1987; Buesseler et al., 2007a; Torres Valdes et al., 2014; Marsay et al., 2015) with several factors proposed to control export flux attenuation. Increased attenuation, i.e., higher $b$ values, have been related to increased temperature (Marsay et al., 2015), zooplankton feeding activity (Lampitt et al., 1990), coprophagy, coprorhexy and coprochaly (Belcher et al. 2016), microbial cycling (Giering et al., 2014) and lack of ballast (Le Moigne et al., 2012). Decreased flux attenuation, i.e., lower $b$ values, and thus higher transfer efficiencies $\left(T_{\text {eff }}\right)$ have been associated to high particle sinking velocity depending on plankton community composition, especially the presence of larger phytoplankton cells (Buesseler, 1998; Buesseler and Boyd, 2009), particle aggregates (Alldredge and Gotschalk, 1989) and fecal pellets (Cavan et al., 2015). Organic polymers, such as transparent exopolymer particles (TEP), increase the rate of aggregate formation due to their high stickiness (Alldredge et al., 1993; Engel, 2000; Passow, 2002; Chow et al., 2015) and supposedly play an important role in particle export fluxes (Passow, 2002; Arrigo, 2007; Chow et al., 2015). TEP are carbon-rich particles that form from dissolved polysaccharides (Engel et al., 2004). When included in sinking POM inventories, TEP may increase carbon relative to nitrogen export fluxes, a mechanism that potentially counteracts rising $\mathrm{CO}_{2}$ concentration in the atmosphere (Schneider et al., 2004; Arrigo, 2007; Engel et al., 2014). However, TEP themselves are non-sinking due to a high water content and low density (Azetzu-Scott and Passow, 2004), and little quantitative data are available on TEP export by sinking particles so far (Passow et al., 2000; Martin et al., 2011; Ebersbach et al., 2014). Thus, the role of TEP in carbon export is still unresolved.

Reduced POC flux attenuation has also been suggested for oxygen minimum zones (OMZs) (Martin et al., 1987; Haake et al., 1992; Devol and Hartnett, 2001; Van Mooy et al., 2002; Keil et al., 2016) as a consequence of reduced zooplankton feeding and microbial degradation activities in suboxic $\left(<5 \mu \mathrm{mol} \mathrm{O}_{2} \mathrm{~kg}^{-1}\right)$ waters. So far, the vast majority of mesopelagic downward POM flux measurements originate from well-oxygenated waters $\left(>100 \mu \mathrm{mol} \mathrm{O} \mathrm{O}_{2} \mathrm{~kg}^{-1}\right)$. In the M87 study, five sets of drifting sediment traps were deployed in the oxygenated North Pacific and four sets were deployed in the eastern tropical North Pacific (ETNP) OMZ. The flux attenuation coefficients $(b)$ for the oxygenated North
Pacific averaged $0.90 \pm 0.06$, while lower $b$ values averaging to $0.66 \pm 0.24$ were measured in the ETNP OMZ. In agreement, Devol and Hartnett (2001) and Van Mooy et al. (2002) observed low particle attenuation in the OMZ of the ETNP off Mexico, yielding $b$ coefficients of 0.36 and 0.40 respectively. Keil et al. (2016) found $b$ values of $0.59-0.63$ in the suboxic Arabian Sea. These studies thus indicate that a greater proportion of the sinking POM escapes degradation while sinking through suboxic waters. However, influence of oxygen on organic matter degradation may vary between individual components. For instance, degradation of hydrolyzable amino acid (PHAA) under suboxic conditions was found to continue with the same rate as compared to oxic conditions (Van Mooy et al., 2002; Pantoja et al., 2004), suggesting that anaerobic and micro-aerobic bacteria preferentially utilize nitrogen-rich components.

So far, little is known on sinking POM flux attenuation in hypoxic waters $\left(<60 \mu \mathrm{mol} \mathrm{O}_{2} \mathrm{~kg}^{-1}\right)$, which are more widespread $(\sim 4 \%$ of ocean volume) compared to suboxic waters $(<0.05 \%$ of ocean volume). Laboratory studies indicated that particle aggregates sinking through hypoxic waters can become suboxic within their interior due to oxygen diffusion limitation and evolve microbial degradation processes typical for suboxic waters (Alldredge and Cohen, 1987; Ploug et al., 1997; Stief et al., 2016). For example, at an ambient $\mathrm{O}_{2}$ concentration of $60 \mu \mathrm{mol} \mathrm{kg}{ }^{-1}$, the $\mathrm{O}_{2}$ uptake by a $2 \mathrm{~mm}$ (diameter) aggregate was diffusion-limited and a $0.5 \mathrm{~mm}$ wide anoxic core occurred within its interior (Ploug and Bergkvist, 2015). Since OMZs are expected to expand in the future as a consequence of global warming and altered circulation patterns (Stramma et al., 2008), the role of oxygen in controlling the biological pump efficiency needs to be better constrained for predicting ocean-climate feedbacks. In order to assess what controls carbon flux attenuation and depth-related changes in sinking particle composition in hypoxic waters, we determined downward POM fluxes in the eastern tropical North Atlantic (ETNA) off the coast of Mauritania, which exhibits an extensive hypoxic OMZ between 300 and $500 \mathrm{~m}$. We used two parallel drifting, surface-tethered sediment trap devices with particle interceptor traps (PITs) at seven to eight different depths between 60 and $600 \mathrm{~m}$ to estimate fluxes to and within the OMZ.

\section{Methods}

\subsection{The study area}

The study was conducted from 17 March to 16 April 2014 during a cruise of the RV Meteor to the ETNA region off the coast of Mauritania (Fig. 1a). The study area included hypoxic waters with minimum values of oxygen concentration of $40 \mu \mathrm{mol} \mathrm{kg}^{-1}$ as determined by CTD (Seabird) casts with two calibrated oxygen sensors at midwater depths of 350$500 \mathrm{~m}$ (Fig. 1b) (Visbeck, 2014). 

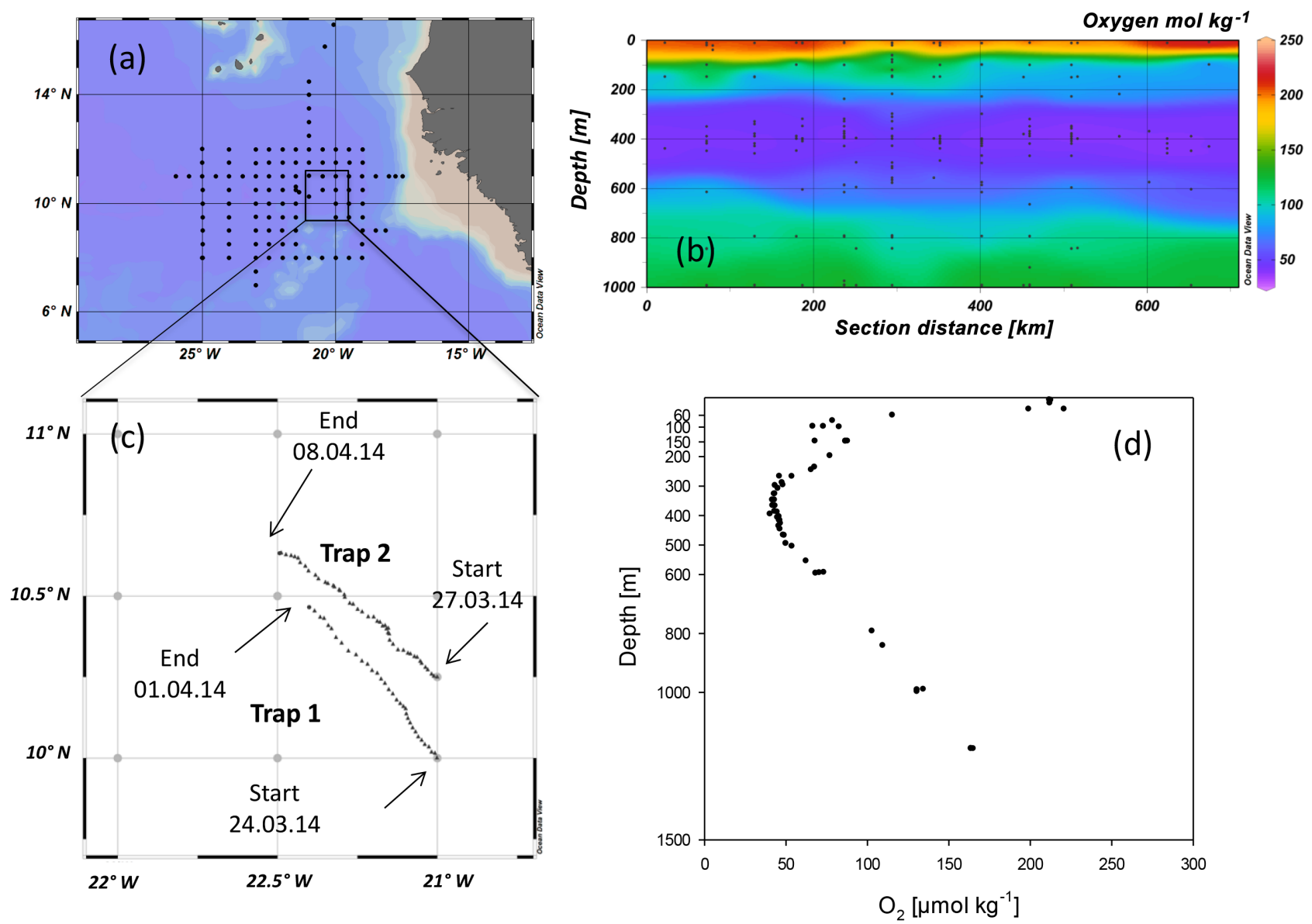

Figure 1. Map of (a) the study area and (b) depth distribution of oxygen concentration $\left(\mathrm{mol} \mathrm{kg}^{-1}\right)$ in the eastern tropical North Atlantic (ETNA) during the RV Meteor 105 cruise, when two surface-tethered drifting sediment traps (STDT) were deployed (c). Depth distribution of oxygen concentration $\left(\mathrm{mol} \mathrm{kg}^{-1}\right)$ at stations visited in the deployment area showed an oxygen minimum zone in the upper mesopelagic (d).

\subsection{Sediment trap operation and sample analysis}

Free-drifting surface-tethered sediment trap devices were deployed for $196 \mathrm{~h}$ during the first deployment and $281 \mathrm{~h}$ during the second deployment (Fig. 1c). The first trap device was deployed on the 24 March 2014 (11:00 UTC) at $10.00^{\circ} \mathrm{N}$ $21.00^{\circ} \mathrm{W}$ with 12 PITs at each of eight depths: 60,100 , $150,200,300,400,500$ and $600 \mathrm{~m}$. The device was recovered on the 1 April 2014 (14:30 UTC) at $10.46^{\circ} \mathrm{N}, 21.39^{\circ} \mathrm{W}$. The second device was deployed on the 27 March 2014 (16:00 UTC) at $10.25^{\circ} \mathrm{N}, 21^{\circ} \mathrm{W}$ with 12 PITs at each of seven depths: 100, 150, 200, 300, 400, 500 and $600 \mathrm{~m}$. The second trap device was recovered on the 8 April 2014 (09:00 UTC) at $10.63^{\circ} \mathrm{N}, 21.50^{\circ} \mathrm{W}$. Both devices slowly drifted northwest and were recovered approximately $37 \mathrm{~nm}$ away from their deployment location (Fig. 1c). Within the drifting area, oxygen concentration in the OMZ resembled the overall pattern of the Mauritanian upwelling with fully hypoxic conditions between 300 and $500 \mathrm{~m}$ (Fig. 1d).

The design of the trap devices and the drifting array basically follows Knauer et al. (1979), with 12 PITs mounted on a polyvinyl chloride (PVC) cross frame. The PITs were acrylic tubes with an inside diameter of $7 \mathrm{~cm}$, an outside diameter of $7.6 \mathrm{~cm}$ and a height of $53 \mathrm{~cm}$, leading to an aspect ratio of 7.5. The aspect ratio and a baffle system consisting of smaller acrylic tubes attached to the top end of each PIT help to reduce drag-induced movement within the trap (Soutar et al., 1977). PVC crosses with PITs were attached to a free-floating line, which was buoyed at the surface and weighted at the bottom. The surface buoys of the arrays carried GPS/Iridium devices and flashlights.

Prior to each deployment, each PIT was filled with $1.5 \mathrm{~L}$ of filtered surface seawater $(0.2 \mu \mathrm{m}$ pore size cartridge $)$ collected from the ship's underway seawater system, up to threequarters of the PIT's height. A brine solution was prepared by dissolving $50 \mathrm{~g} \mathrm{~L}^{-1}$ sodium chloride with filtered surface seawater and subsequently filtered through a $0.2 \mu \mathrm{m}$ cartridge to remove excess particulates. Then $20 \mathrm{~mL}$ of formalin was added per liter of the solution to achieve a brine solution with $2 \%$ formalin. The preservative solution was then slowly transferred into each PIT beneath the $1.5 \mathrm{~L}$ of filtered sea- 
water using a peristaltic pump. PITs were covered with lids immediately to minimize contamination before deployment.

Sample treatment after trap recovery followed recommendations given by Buesseler et al. (2007b). After recovery, all PITs were capped to minimize contamination. The density gradient was visually inspected and found intact at the position of prior to deployment or at a maximum $2 \mathrm{~cm}$ above. Then, seawater was pumped out of each PIT using a peristaltic pump down to $2-3 \mathrm{~cm}$ above the density gradient. The remaining $\sim 0.6 \mathrm{~L}$ was subsequently transferred to canisters, pooled from 11 tubes per depth. Added to each canister was $40 \mathrm{~mL}$ formalin. Samples from each depth were passed through a $500 \mu \mathrm{m}$ nylon mesh. Swimmers were removed from the mesh with forceps under a binocular microscope and the remaining particles, which stuck to the mesh, were transferred back to the sample. Samples were subsequently split into aliquots of the total sample. Therefore, the pooled sample was transferred into a round $10 \mathrm{~L}$ canister and stirred at medium velocity with a magnetic bar. Aliquots were transferred into $0.5 \mathrm{~L}$ Nalgene bottles with a flexible tube using a peristaltic pump. Aliquots of samples were filtered under low pressure $(<200 \mathrm{mbar})$ onto different filter types (combusted GF/F $0.7 \mu \mathrm{m}$, polycarbonate $0.4 \mu \mathrm{m}$ or cellulose acetate $0.8 \mu \mathrm{m}$; see below) for different analyses and stored frozen $\left(-20^{\circ} \mathrm{C}\right)$ until analyses.

\section{Biogeochemical analyses}

The following parameters were determined: total particulate mass (TPM), POC, particulate nitrogen (PN), particulate organic phosphorus (POP), biogenic silica (BSi), chlorophyll $a$ (Chl $a$ ), particulate PHAA and TEP.

TPM was analyzed in triplicate. The following aliquots were filtered in triplicate onto pre-weighed $0.4 \mu \mathrm{m}$ polycarbonate filters: $800 \mathrm{~mL}(2 \times 400 \mathrm{~mL} ; 8 \%$ of total sample $)$ for the depths of 600 to $300 \mathrm{~m}$ of deployment no. 1, $400 \mathrm{~mL}$ (4\% of total sample) for the depths of 200 and $150 \mathrm{~m}$ of deployment no. 1 and for all depths of deployment no. 2, and $420 \mathrm{~mL}$ ( $4 \%$ of total sample) for the depth of 100 and $60 \mathrm{~m}$ of deployment no. 1. Filters were rinsed twice with Milli-Q water, dried at $60^{\circ} \mathrm{C}$ for $4 \mathrm{~h}$ and stored until weight measurement on a Mettler Toledo XP2U microbalance.

$\mathrm{POC}$ and $\mathrm{PN}$ aliquots were filtered in triplicate onto combusted $\left(8 \mathrm{~h}\right.$ at $500^{\circ} \mathrm{C}$ ) $\mathrm{GF} / \mathrm{F}$ filters (Whatmann, $25 \mathrm{~mm}$ ): $400 \mathrm{~mL}$ ( $4 \%$ of total sample) for the depths of 600 to $150 \mathrm{~m}$ of deployment no. $1,420 \mathrm{~mL}$ ( $4 \%$ of total sample) for the depths of 100 and $60 \mathrm{~m}$ of deployment no. 1 , and $100 \mathrm{~mL}$ ( $1 \%$ of total sample) for all depths of deployment no. 2. For the depths of 150, 100 and $60 \mathrm{~m}$ of deployment no. 1, 400$420 \mathrm{~mL}$ ( $4 \%$ of total sample) was filtered onto two filters due to the high particle load at these depths. Filters were exposed to fuming hydrochloric acid in a fuming box overnight to remove carbonate and subsequently dried $\left(60^{\circ} \mathrm{C}, 12 \mathrm{~h}\right)$. For analysis, the filters were enclosed in tin cups and analyzed using an Euro EA elemental analyzer calibrated with an ac- etanilide standard. For the depths of 150, 100 and $60 \mathrm{~m}$ of deployment no. 1 the sum of both filters was taken.

POP was determined in triplicate, except for $60 \mathrm{~m}$ depth of deployment no. 1 , which was only determined in duplicate. The following aliquots were filtered onto combusted GF/F filters (Whatmann, $25 \mathrm{~mm}$ ): $400 \mathrm{~mL}$ ( $4 \%$ of total sample) for the depths of 600 to $150 \mathrm{~m}$ of deployment no. $1,420 \mathrm{~mL}(4 \%$ of total sample) for the depths of 100 and $60 \mathrm{~m}$ of deployment no. 1 , and $100 \mathrm{~mL}$ ( $1 \%$ of total sample) for all depths of deployment no. 2. For the depths of 200 to $60 \mathrm{~m}$ of deployment no. 1 , the volume of $400 \mathrm{~mL} / 420 \mathrm{~mL}$ ( $4 \%$ of total sample) was filtered onto two filters due to the high particle load at these shallower depths. Organic phosphorus collected on the filters was digested in the potassium peroxodisulfatecontaining substance Oxisolv (Merck) for $30 \mathrm{~min}$ in a pressure cooker and measured colorimetrically as orthophosphate following the method of Hansen and Koroleff (1999).

PHAAs were determined in duplicate. The following aliquots were filtered onto combusted GF/F filters $(25 \mathrm{~mm})$ : $400 \mathrm{~mL}$ ( $4 \%$ of total sample) for the depths of $600 \mathrm{~m}$ to $150 \mathrm{~m}$ of deployment no. $1,420 \mathrm{~mL}$ ( $4 \%$ of total sample) for the depths of $100 \mathrm{~m}$ and $60 \mathrm{~m}$ of deployment no. 1 , and $100 \mathrm{~mL}$ ( $1 \%$ of total sample) for all depths of deployment no. 2. For the depths of 150,100 and $60 \mathrm{~m}$ of deployment no. 1 , the volume of $400 \mathrm{~mL} / 420 \mathrm{~mL}$ ( $4 \%$ of total sample) was filtered onto two filters due to the high particle load at these shallower depths. PHAA analysis was performed according to Lindroth and Mopper (1979) and Dittmar et al. (2009) with some modifications. Duplicate samples were hydrolyzed for $20 \mathrm{~h}$ at $100^{\circ} \mathrm{C}$ with hydrochloric acid $(30 \%$, Suprapur, Merck) and neutralized by acid evaporation under vacuum in a microwave at $60^{\circ} \mathrm{C}$. Samples were washed with water to remove remaining acid. Analysis was performed on a 1260 HPLC system (Agilent). Thirteen different amino acids were separated with a C18 column (Phenomenex Kinetex, $2.6 \mu \mathrm{m}, 150 \times 4.6 \mathrm{~mm}$ ) after in-line derivatization with o-phthalaldehyde and mercaptoethanol. The following standard amino acids were used: aspartic acid (AsX), glutamic acid (GlX), histidine (His), serine (Ser), arginine (Arg), glycine (Gly), threonine (Thr), alanine (Ala), tyrosine (Tyr), valine (Val), phenylalanine (Phe), isoleucine (Ileu), leucine (Leu) and $\gamma$-amino butyric acid (GABA). $\alpha$-Amino butyric acid was used as an internal standard to account for losses during handling. Solvent A was $5 \%$ acetonitrile (LiChrosolv, Merck, HPLC gradient grade) in sodium dihydrogen phosphate (Merck, Suprapur) buffer ( $\mathrm{pH}$ 7.0); solvent B was acetonitrile. A gradient was run from $100 \%$ solvent A to $78 \%$ solvent $\mathrm{A}$ in $50 \mathrm{~min}$. The detection limit for individual amino acids was $2 \mathrm{nmol}$ monomer $\mathrm{L}^{-1}$. The precision was $<5 \%$, estimated as the standard deviation of replicate measurements divided by the mean. The degradation index (DI) was calculated from the amino acid composition following Dauwe et al. (1999).

$\mathrm{BSi}$ was determined in triplicate. The following aliquots were filtered onto cellulose acetate filters $(0.8 \mu \mathrm{m}): 400 \mathrm{~mL}$ 
( $4 \%$ of total sample) for the depths of $600 \mathrm{~m}$ to $150 \mathrm{~m}$ of deployment no. $1,420 \mathrm{~mL}$ ( $4 \%$ of total sample) for the depths of $100 \mathrm{~m}$ and $60 \mathrm{~m}$ of deployment no. 1 , and $200 \mathrm{~mL}$ $(2 \times 100 \mathrm{~mL} ; 2 \%$ of total sample) for all depths of deployment no. 2. Filters were incubated with $25 \mathrm{~mL} \mathrm{NaOH}(0.1 \mathrm{M})$ at $85^{\circ} \mathrm{C}$ for $2 \mathrm{~h} 15 \mathrm{~min}$ in a shaking water bath. After cooling of the samples, analysis was conducted according to the method for determination of $\mathrm{Si}(\mathrm{OH})_{4}$ by Hansen and Koroleff (1999). Fluxes of biogenic opal were calculated assuming a water content of $\sim 10 \%$ and therefore the chemical formula $\mathrm{SiO}_{2} \times 0.4 \mathrm{H}_{2} \mathrm{O}$ with a density of $\sim 2.1 \mathrm{~g} \mathrm{~cm}^{-3}$ (Mortlock and Fröhlich 1989).

Chl $a$ was determined in duplicate. The following aliquots were filtered onto GF/F filters ( $25 \mathrm{~mm}$ ): $400 \mathrm{~mL}$ ( $4 \%$ of total sample) for the depths of 600 to $150 \mathrm{~m}$ of deployment no. 1, $420 \mathrm{~mL}$ ( $4 \%$ of total sample) for the depths of $100 \mathrm{~m}$ and $60 \mathrm{~m}$ of deployment no. 1 , and $100 \mathrm{~mL}$ ( $1 \%$ of total sample) for all depths of deployment no. 2. For the depths of 200 to $60 \mathrm{~m}$ of deployment no. 1 , the volume of $400 \mathrm{~mL} / 420 \mathrm{~mL}$ ( $4 \%$ of total sample) was filtered onto two filters due to the high particle load at these shallower depths. Samples were analyzed after extraction with $10 \mathrm{~mL}$ of acetone $(90 \%)$ on a Turner fluorimeter after Welschmeyer (1994). Calibration of the instrument was conducted with spinach extract standard (Sigma Aldrich).

TEP were determined in quadruplet by microscopy after Engel (2009). Between 3.5 and $10 \mathrm{~mL}(0.03-0.1 \%$ of total sample) for the depths of deployment no. 1 and no. 2 were filtered onto $0.4 \mu \mathrm{m}$ Nuclepore membrane filters (Whatmann) and stained with $1 \mathrm{~mL}$ Alcian Blue solution. Filters were mounted onto Cytoclear $\odot$ slides and stored at $-20^{\circ} \mathrm{C}$ until microscopy analysis using a light microscope (Zeiss Axio Scope A.1) connected to a camera (AxioCam MRc). Filters were screened at 200x magnification. Thirty pictures were taken randomly from each filter in two perpendicular cross sections (15 pictures each; resolution $1040 \times 1040$ pixel, 8bit color depth). Image analysis software WCIF ImageJ (version 1.44, public domain, developed at the US National Institutes of Health, courtesy of Wayne Rasband, National Institute of Mental Health, Bethesda, Maryland) was used to semiautomatically analyze particle numbers and area.

The carbon content of TEP (TEP-C) was estimated after Mari (1999) using the size-dependent relationship:

$\mathrm{TEP}-\mathrm{C}=a \Sigma_{i}\left(n_{i} r_{i}^{D}\right)$,

with $n_{i}$ being the number of TEP in the size class $i$ and $r_{i}$ the mean equivalent spherical radius of the size class. The constant $a=0.25 \times 10^{-6}(\mu \mathrm{g} \mathrm{C})$ and the fractal dimension of aggregates $D=2.55$ were proposed by Mari (1999). TEP$\mathrm{C}$ was only calculated for the size fraction $<5 \mu \mathrm{m}$, including mainly free TEP, because larger TEP included TEP covered aggregates with solid particles. Estimating carbon content of these larger particles would overestimate TEP-C as the volume of the other particles would be included.

\subsection{Calculations and statistics}

Fluxes of $\mathrm{CaCO}_{3}$ and lithogenic matter (lith) were calculated as

$\left[\mathrm{CaCO}_{3}+\right.$ lith $]=[\mathrm{TPM}]-[\mathrm{POM}]-[\mathrm{Opal}]$.

Total mineral ballast (ballast total $_{\text {) was calculated as }}$

$\left[\right.$ ballast $\left._{\text {total }}\right]=[\mathrm{TPM}]-[\mathrm{POM}]$.

The percentage of ballast $t_{\text {total }}$ (\%ballast total ) was calculated as

$\left[\%\right.$ ballast $\left._{\text {total }}\right]=([\mathrm{TPM}]-[\mathrm{POM}]) /[\mathrm{TPM}] \times 100$.

The transfer efficiency ( $\left.T_{\text {eff }}\right)$ of particulate components was calculated as the ratio of fluxes at $600 \mathrm{~m}$ to those at $100 \mathrm{~m}$.

Calculated mean values include replicate measurements of both deployments. Data fits and statistical tests were performed with the software packages Microsoft Office Excel 2010, Sigma Plot 12.0 (Systat) and Ocean Data View 4 (ODV) (Schlitzer, 2015). Weighted-average gridding was used in ODV to display data according to data coverage with automatic scale lengths. The overall significance level was $p<0.05$.

\section{Results and discussion}

\subsection{Fluxes of different compounds}

Export fluxes of TPM and particulate organic elements determined during both trap deployments showed good overall agreement and a decrease with depth, fitting well to the power law function of M87 (Figs. 2a-d, 3a-d and Table 1). Averaging fluxes from both deployments yielded a total mass flux of $240 \pm 34 \mathrm{mg} \mathrm{m}^{-2} \mathrm{~d}^{-1}$ at $100 \mathrm{~m}$ decreasing to $141 \pm 8.8 \mathrm{mg} \mathrm{m}^{-2} \mathrm{~d}^{-1}$ in the core of the OMZ $(400 \mathrm{~m})$ (Fig. 2a). Fluxes of POC, PN and POP at $100 \mathrm{~m}$ depth were $73 \pm 8.8,13 \pm 1.4$ and $0.67 \pm 0.06 \mathrm{mg} \mathrm{m}^{-2} \mathrm{~d}^{-1}$, respectively, and decreased to $26 \pm 4.5,3.0 \pm 0.41$ and $0.19 \pm 0.04 \mathrm{mg} \mathrm{m}^{-2} \mathrm{~d}^{-1}$ at $400 \mathrm{~m}$ depth (Fig. 2b-d). The contribution of POC flux to total mass flux (\% OC) decreased from about $30 \%$ at $60-150 \mathrm{~m}$ depth to $17-20 \%$ at $400 \mathrm{~m}$ depth and showed only a minor decrease below $400 \mathrm{~m}$, to $14-16 \%$ at $600 \mathrm{~m}$ depth. Similarly, the percentage of PN flux to total mass flux $(\% \mathrm{~N})$ showed the largest decrease between 60 and $400 \mathrm{~m}$, i.e., from 6.6 to $2.0-2.3 \%$, with less decline observed below, reaching $1.7-1.8 \%$ at $600 \mathrm{~m}$. The percentage of POP flux to total mass flux (\% P) decreased from $0.37 \%$ at $60 \mathrm{~m}$ depth to $0.11-0.16 \%$ at $400 \mathrm{~m}$ depth and remained constant below $400 \mathrm{~m}$ depth. No previous data are available for POM export fluxes at our study site for direct comparison. However, our trap data compare well to carbon export fluxes estimated from particle size data (i.e., 10$300 \mathrm{mg} \mathrm{C} \mathrm{m}^{-2} \mathrm{~d}^{-1}$ ) reported for $100 \mathrm{~m}$ depth in the area off Cape Blanc (Mauritania) by Iversen et al. (2010). 
Table 1. Fluxes of particulate components at $100 \mathrm{~m}$ depth $\left(F_{100}\right)$ and in the core of the $\mathrm{OMZ}$ at $400 \mathrm{~m}\left(F_{\mathrm{OMZ}}\right)$, as well as the associated attenuation coefficients ( $b$ values) and transfer efficiencies $\left(T_{\text {eff }}, \%\right)$ over the depth range of 100 to $600 \mathrm{~m}$ during two traps deployments in the ETNA. All units are in $\mathrm{mg} \mathrm{m}^{-2} \mathrm{~d}^{-1}$ except for TEP fluxes, which is reported in total particle area $\mathrm{cm}^{-2} \mathrm{~m}^{-2} \mathrm{~d}^{-1}$. Mean values and standard deviations (SD) were calculated from analytical replicates.

\begin{tabular}{llrr|rr|rrrrr}
\hline \multirow{2}{*}{ Component } & & \multicolumn{2}{c}{$F_{100}$} & \multicolumn{2}{c}{$F_{\text {OMZ }}$} & \multicolumn{2}{c}{$b$ value } & & $T_{\text {eff }}(\%)$ \\
\cline { 3 - 8 } & & mean & SD & mean & SD & mean & SD & $r^{2}$ & $(600 / 100 \mathrm{~m})$ \\
\hline Mass & I & 249 & 48.9 & 141 & 6.8 & -0.429 & 0.090 & 0.987 & 41 \\
& II & 231 & 16.3 & 141 & 12.1 & -0.355 & 0.033 & 0.998 & 52 \\
POC & I & 69.4 & 9.23 & 23.8 & 5.4 & -0.795 & 0.031 & 0.989 & 23 \\
& II & 76.3 & 8.43 & 28.1 & 3.0 & -0.741 & 0.044 & 0.989 & 22 \\
PN & I & 11.9 & 1.29 & 2.76 & 0.46 & -1.013 & 0.026 & 0.992 & 15 \\
& II & 13.5 & 1.12 & 3.26 & 0.19 & -1.00 & 0.020 & 0.990 & 16 \\
POP & I & 0.71 & 0.07 & 0.15 & 0.02 & -1.081 & 0.074 & 0.992 & 18 \\
& II & 0.64 & 0.03 & 0.22 & 0.02 & -0.80 & 0.034 & 0.990 & 23 \\
Opal & I & 44.6 & 1.76 & 34.0 & 1.7 & -0.0195 & 0.038 & 0.987 & 65 \\
& II & 48.6 & 4.16 & 30.7 & 2.0 & -0.345 & 0.052 & 0.987 & 44 \\
Chl $a$ & I & 0.10 & 0.00 & 0.035 & 0.001 & -0.820 & 0.024 & 0.990 & 21 \\
& II & 0.12 & 0.01 & 0.053 & 0.005 & -0.625 & 0.082 & 0.988 & 24 \\
TEP & I & 1650 & 548 & 1190 & 368 & -0.498 & 0.014 & 0.548 & 33 \\
& II & 2990 & 348 & 1644 & 95 & -0.451 & 0.069 & 0.810 & 37 \\
PHAA-C & I & 3.21 & - & 3.71 & 0.47 & -1.324 & 0.067 & 0.994 & 11 \\
& II & 1.28 & 0.10 & 5.24 & 0.79 & -0.978 & 0.096 & 0.991 & 14 \\
\hline
\end{tabular}

Fluxes of phytoplankton biomass, as indicated from Chl $a$, were similar at $100 \mathrm{~m}$ during both deployments, with $104 \pm 1.5 \mu \mathrm{g}$ Chl $a \mathrm{~m}^{-2} \mathrm{~d}^{-1}$ during the first and $116 \pm 6.2 \mu \mathrm{g} \mathrm{m}^{-2} \mathrm{~d}^{-1}$ during the second deployment, but behaved differently below, with a stronger flux attenuation above the OMZ during the first compared to the second deployment (Fig. 3a). Fluxes within the OMZ core were $35 \pm 0.1 \mu \mathrm{g} \mathrm{m}^{-2} \mathrm{~d}^{-1}$ (no. 1) and $53 \pm 0.5 \mu \mathrm{g} \mathrm{m}^{-2} \mathrm{~d}^{-1}$ (no. 2) respectively.

Opal fluxes were also similar during both deployments, yielding an average of $47 \pm 3.6 \mathrm{mg} \mathrm{m}^{-2} \mathrm{~d}^{-1}$ at $100 \mathrm{~m}$, steadily decreasing to $32 \pm 2.4 \mathrm{mg} \mathrm{m}^{-2} \mathrm{~d}^{-1}$ at $400 \mathrm{~m}$ depth (Fig. 3b). Similar to Chl $a$, opal fluxes were slightly higher above the OMZ during the second compared to the first deployment but quite similar or even lower below the OMZ. This may indicate that the second trap device, which drifted more northerly (Fig. 1c), exploited waters of a more recent diatom bloom compared to the first deployment.

Fluxes of $\left[\mathrm{CaCO}_{3}+\right.$ lith] were similar to opal fluxes during the first deployment $\left(F_{100}=52 \mathrm{mg} \mathrm{m}^{-2} \mathrm{~d}^{-1}\right)$ but considerably lower during the second $\left(F_{100}=14.8 \mathrm{mg} \mathrm{m}^{-2} \mathrm{~d}^{-1}\right)$ (data not shown).

During this study, export fluxes of TEP were estimated from decrease over depth of total particle area and showed the strongest depth attenuation between 60 and $100 \mathrm{~m}$ during the first deployment (Fig. 3c). Like Chl $a$ fluxes, TEP export fluxes were slightly higher during the second compared to the first deployment. At $100 \mathrm{~m}$ depth, average TEP flux was $2323 \pm 859 \mathrm{~cm}^{2} \mathrm{~m}^{-2} \mathrm{~d}^{-1}$ and decreased to $1418 \pm 342 \mathrm{~cm}^{2} \mathrm{~m}^{-2} \mathrm{~d}^{-1}$ at $400 \mathrm{~m}$. Using a TEP size to car- bon conversion according to Mari (1999) yielded to an average TEP-C $(<5 \mu \mathrm{m})$ flux of $1.73 \pm 0.35 \mathrm{mg} \mathrm{C} \mathrm{m}^{-2} \mathrm{~d}^{-1}$ at $100 \mathrm{~m}$ depth, slightly decreasing to $1.64 \pm 0.28 \mathrm{mg} \mathrm{m}^{-2} \mathrm{~d}^{-1}$ at $400 \mathrm{~m}$ and further to $0.90 \pm 0.32 \mathrm{mg} \mathrm{m}^{-2} \mathrm{~d}^{-1}$ at $600 \mathrm{~m}$. Although TEP supposedly play an important role in particle export fluxes (Passow, 2002; Arrigo, 2007; Chow et al., 2015), only a few previous estimates for TEP export fluxes based on sediment traps have been given so far to which we can compare our data. Martin et al. (2011) measured TEP export fluxes during a spring bloom in the Iceland Basin (northeast Atlantic Ocean) using the PELAGRA neutrally buoyant sediment traps and determined values in the range of $30-120 \mathrm{mg}$ xanthan gum equivalent $\mathrm{m}^{-2} \mathrm{~d}^{-1}$. Ebersbach et al. (2014) obtained lower values of $0.03-5.14 \mathrm{mg}$ xanthan gum equivalent $\mathrm{m}^{-2} \mathrm{~d}^{-1}$ during the LOHAFEX iron fertilization experiment in the Southern Ocean. Assuming a conversion factor

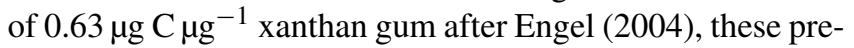
vious estimates suggest TEP-C export fluxes ranging from 0.02 to $3 \mathrm{mg} \mathrm{m}^{-2} \mathrm{~d}^{-1}$ for the Southern Ocean and from 19 to $75 \mathrm{mg} \mathrm{m}^{-2} \mathrm{~d}^{-1}$ for the North Atlantic spring bloom. Our data on TEP export fluxes for ETNA region are within the range of these previous studies but closer to the lower estimates for the Southern Ocean. It has to be emphasized, though, that our calculated TEP-C fluxes are likely underestimates, since only suspended, i.e., "free" TEP $<5 \mu \mathrm{m}$, were taken into account. TEP-C associated to aggregates cannot be determined with the applied microscopic technique. Overall, TEP-C export fluxes in the ETNA were significantly related to Chl $a$ fluxes, yielding [TEP-C, $\mathrm{mg} \mathrm{m}^{-2} \mathrm{~d}^{-1}$ ] $=11.9$ $\left[\mathrm{Chl} a ; \mathrm{mg} \mathrm{m}^{-2} \mathrm{~d}^{-1}\right]+0.74\left(r^{2}=0.59, n=15, p<0.01\right)$. 

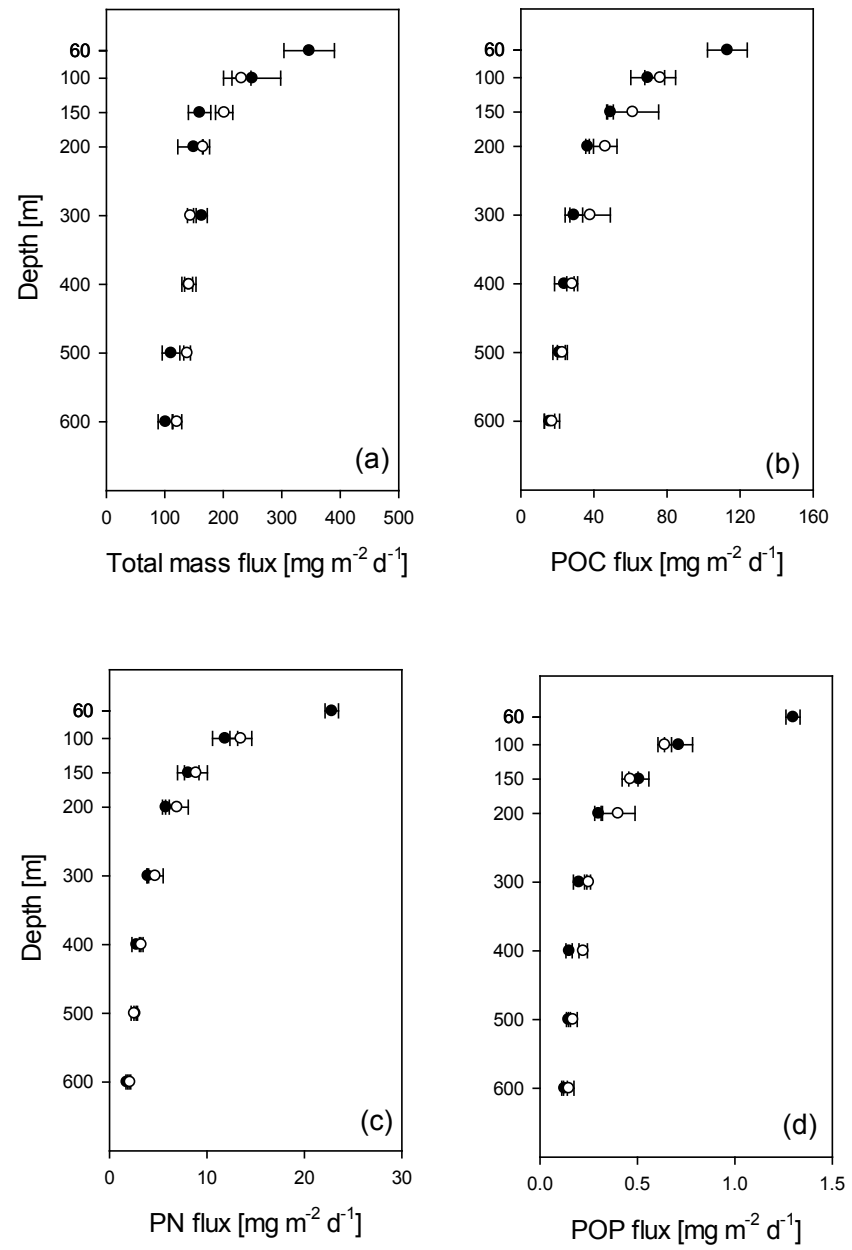

Figure 2. Fluxes of (a) total mass and (b) particulate organic carbon (POC), (c) particulate nitrogen $(\mathrm{PN})$ and (d) particulate organic phosphorus (POP) during the deployment of two STDT in the ETNA. Solid symbols are used for deployment no. 1 and open symbols for deployment no. 2 .

A strong decrease at shallow depth (60-100 m) was also observed for PHAA fluxes during the first deployment (Fig. 3d). Average PHAA fluxes were $330 \pm 51 \mu \mathrm{mol} \mathrm{m} \mathrm{m}^{-1}$ at $100 \mathrm{~m}$ and $90 \pm 20 \mu \mathrm{mol} \mathrm{m}^{-2} \mathrm{~d}^{-1}$ in the OMZ core at $400 \mathrm{~m}$. These fluxes are equivalent to amino-acid-related fluxes of $16.8 \pm 2.6(100 \mathrm{~m})$ and $4.48 \pm 1.0 \mathrm{mg} \mathrm{C} \mathrm{m}^{-2} \mathrm{~d}^{-1}(400 \mathrm{~m})$, respectively, which are typical values for PHAA-C fluxes in the ocean (Lee and Cronin, 1984). PHAA fluxes decreased slightly within the OMZ, i.e., from 300 to $500 \mathrm{~m}$.

\subsection{Flux attenuation in the ETNA OMZ}

Fluxes from both deployments were fitted to the exponential decrease model (Martin et al., 1987) and attenuation coefficients ( $b$ values) were estimated for all components (Table 1 ). Higher $b$ values suggest stronger attenuation and may hint to
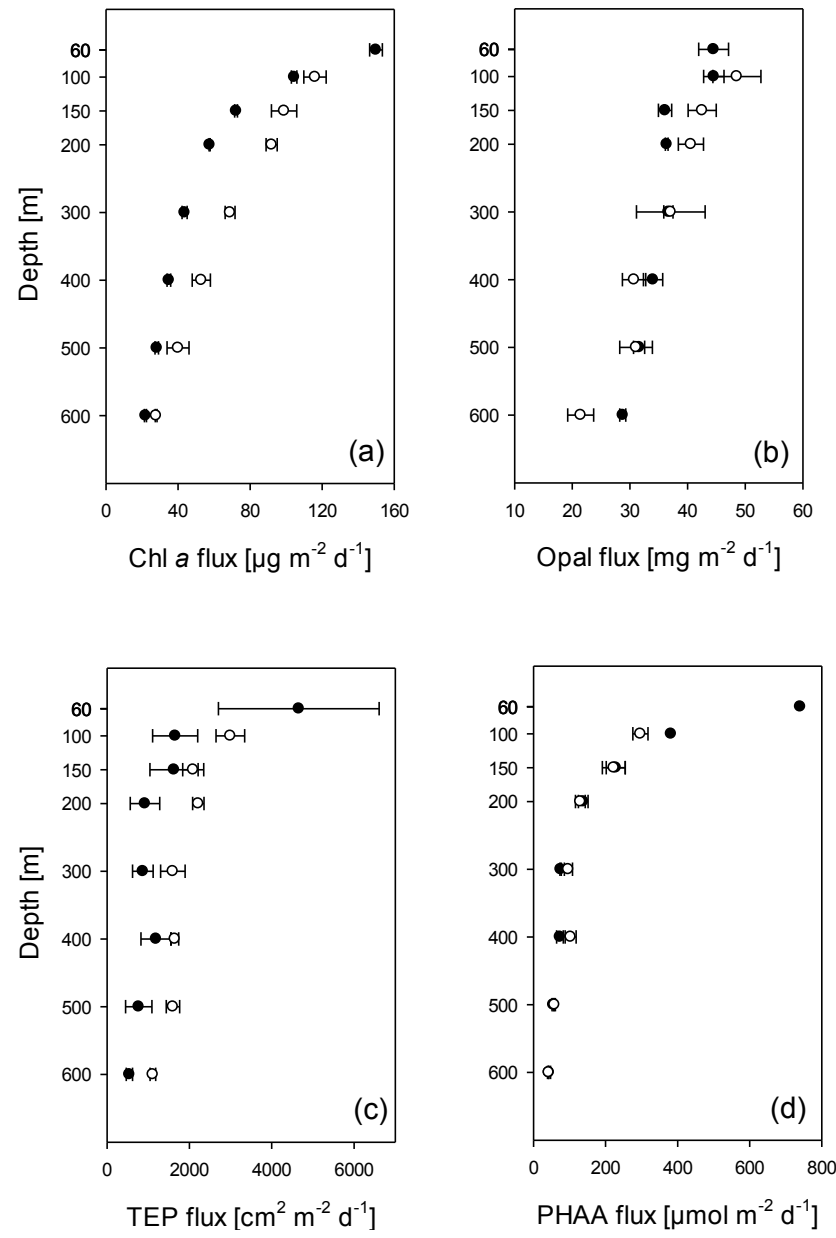

Figure 3. Fluxes of (a) chlorophyll $a$ (Chl $a$ ), (b) opal, (c) TEP and (d) PHAA during the deployment of two STDT in the ETNA. Solid symbols are used for deployment no. 1 and open symbols for deployment no. 2 .

either reduced sinking velocities of particles or faster degradation of more labile components. During this study, PHAAs were the most rapidly attenuated components of sinking particles, followed by POP, PN, POC, Chl $a$ and TEP (Table 1). Attenuation of mineral fluxes was less pronounced than for TPM.

Attenuation coefficient of POC export fluxes was 0.80 during the first and 0.74 during the second deployment. These values are in the intermediate range of previously determined $b$ values for POC attenuation in the mesopelagic, shown to vary between 0.51 as determined in the North Pacific (K2) and 1.59 as determined for the North Atlantic subpolar gyre (NASG) (Buesseler et al., 2007a; Marsay et al., 2015). Based on trap data from fully oxygenated water columns, Marsay et al. (2015) recently suggested a linear relationship between POC flux attenuation and median water temperature within the upper $500 \mathrm{~m}$ of the water column according to $b=0.062 T+0.303$. Applying this relationship to our study 
area, with temperature decreasing from $26^{\circ} \mathrm{C}$ at the surface to $9^{\circ} \mathrm{C}$ at $500 \mathrm{~m}$ and a median temperature value of $12.01^{\circ} \mathrm{C}$, would give a $b$ value of 1.05 . This estimated $b$ value is higher than the values observed in this study $(0.74-0.80)$ and suggests that oxygen deficiency may reduce attenuation of POC fluxes in the ETNA, resulting in higher $T_{\text {eff }}$ of organic matter though the OMZs compared to well-oxygenated waters.

Differences in flux attenuation coefficients translate into different $T_{\text {eff }}$ for individual components, with PHAA being the least and TEP being the most efficiently exported organic component (Table 1). In particular, values of $T_{\text {eff }}$ for TEP and therewith for TEP-C were about 3 times higher than for PHAA-C and even higher than for bulk POC, suggesting a preferential export of carbon included in TEP below $100 \mathrm{~m}$. However, a steep decrease of TEP flux was observed between 60 and $100 \mathrm{~m}$ during the first deployment. TEP are produced by a variety of organisms, i.e., different phytoplankton and bacterial species, and cannot be considered as of homogenous composition. Several mechanisms may therefore be responsible for a change in TEP transfer efficiency with depth: (1) change of TEP degradability with depth; (2) differences in TEP composition over depth related to association with particles of different settling speed; (3) new production of TEP, abiotically or by bacteria, during solubilization and degradation of sinking particles; (4) capture of suspended TEP by sinking aggregates; or (5) reduced degradation rate of TEP at lower oxygen. In support of the latter hypothesis, an attenuation of TEP fluxes within the OMZ (300-500 m) was not detectable but did occur again below the OMZ.

\subsection{Changes in POM composition during export}

POM, assumed to be $2.2 \times$ [POC] following Klaas and Archer (2002), made the greatest contribution to TPM flux at $60 \mathrm{~m}$ but decreased below. Conversely, [\% ballast total] increased with depth, namely from $30 \% w / w$ at $60 \mathrm{~m}$ to $68 \%$ $w / w$ at $600 \mathrm{~m}$.

Biogenic opal (density: $2.1 \mathrm{~g} \mathrm{~cm}^{-3}$ ) in the ocean is produced mainly by diatoms and radiolaria. During this study, opal made a rather constant contribution to TPM fluxes with 20-25\% weight below $100 \mathrm{~m}$. Hence, the observed increase in the [\% ballast $\left.t_{\text {total }}\right]$ with depth was due to an increasing contribution of $\mathrm{CaCO}_{3}$ and lithogenic material. $\left[\mathrm{CaCO}_{3}+\right.$ lith] to TPM increased from 10 to $15 \%$ above $150 \mathrm{~m}$ to $45 \%$ at $600 \mathrm{~m}$. As a consequence, the ballast ratio, defined as [Opal]: $\left[\mathrm{CaCO}_{3}+\right.$ lith], changed from a dominance of opal above the $\mathrm{OMZ}$ to a dominance $\left[\mathrm{CaCO}_{3}+\right.$ lith] within and below the OMZ (Fig. 4). Slight differences were observed between the two deployments. Contribution of opal and of $\left[\mathrm{CaCO}_{3}+\right.$ lith] to TPM at $100 \mathrm{~m}$ was almost equal during the first deployment with a share of 18 and $22 \%$ respectively. During the second deployment the contribution of opal to TPM at $100 \mathrm{~m}$ was $21 \%$ but only $6 \%$ for $\left[\mathrm{CaCO}_{3}+\right.$ lith]. Thus, the higher contribution of opal to TPM fluxes together with higher $\mathrm{Chl} a$ fluxes indicated that diatomaceous mate-

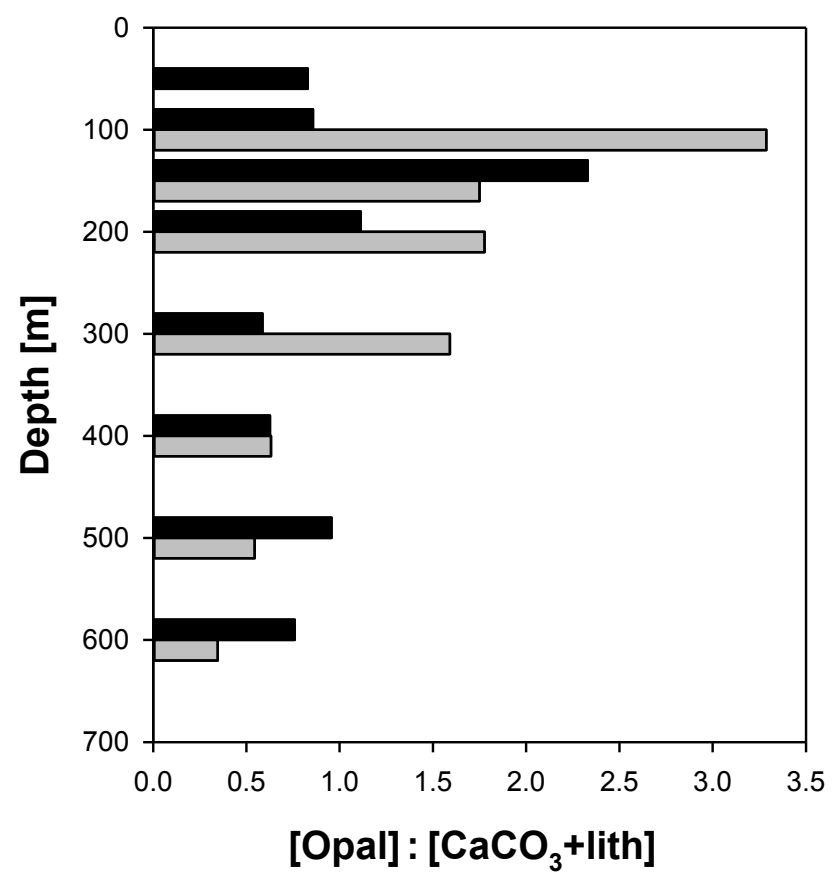

Figure 4. Changes in mineral ballast ratios of sinking particles with depth during the two deployments in the ETNA. Black bars are used for deployment no. 1 and gray bars for deployment no. 2 .

rial had a higher share of particles sinking out of the euphotic zone down to the $\mathrm{OMZ}$ core during the second compared to the first deployment.

Molar [POC]: [PN] ratios were close to the Redfield ratio at depths shallower than $100 \mathrm{~m}$, increased to a ratio of 10 at $400 \mathrm{~m}$ depth and remained constant between 400 and $600 \mathrm{~m}$ depth (Fig. 5a). [PN] : [POP] ratios were much above Redfield, with values varying between 30 and 45 throughout the water column (Fig. 5b). Also, [POC]: [POP] ratios were much higher than Redfield ratios and showed an increasing trend down to 300-400 m depth, while decreasing below (Fig. 5c). These changes in elemental ratios suggested a preferential remineralization of POP in the upper $300 \mathrm{~m}$, followed by PN and POC deeper down.

The percentage of total organic matter in TPM fluxes decreased from $67 \%$ at $100 \mathrm{~m}$ to $32 \%$ at $600 \mathrm{~m}$ (Fig. 6d). As a consequence of higher $T_{\text {eff }}$ of TEP relative to bulk POC, contribution of TEP-C to POC increased significantly with depth during both deployments $\left(p<0.01 ; r^{2}=0.59, n=15\right)$ and was $2 \%$ at $100 \mathrm{~m}$ and $6 \%$ within and $5 \%$ below the OMZ (Fig. 5e). Because TEP are neutrally buoyant, their export to depth depends on their incorporation into settling aggregates. In a laboratory study, Engel et al. (2009) observed that decomposition of TEP was faster relative to bulk POC for aggregates formed from calcifying and non-calcifying Emiliania huxleyi cultures. In that experiment, aggregate decomposition was investigated under oxic conditions. Other studies also showed fast microbial degradation of TEP under oxic 

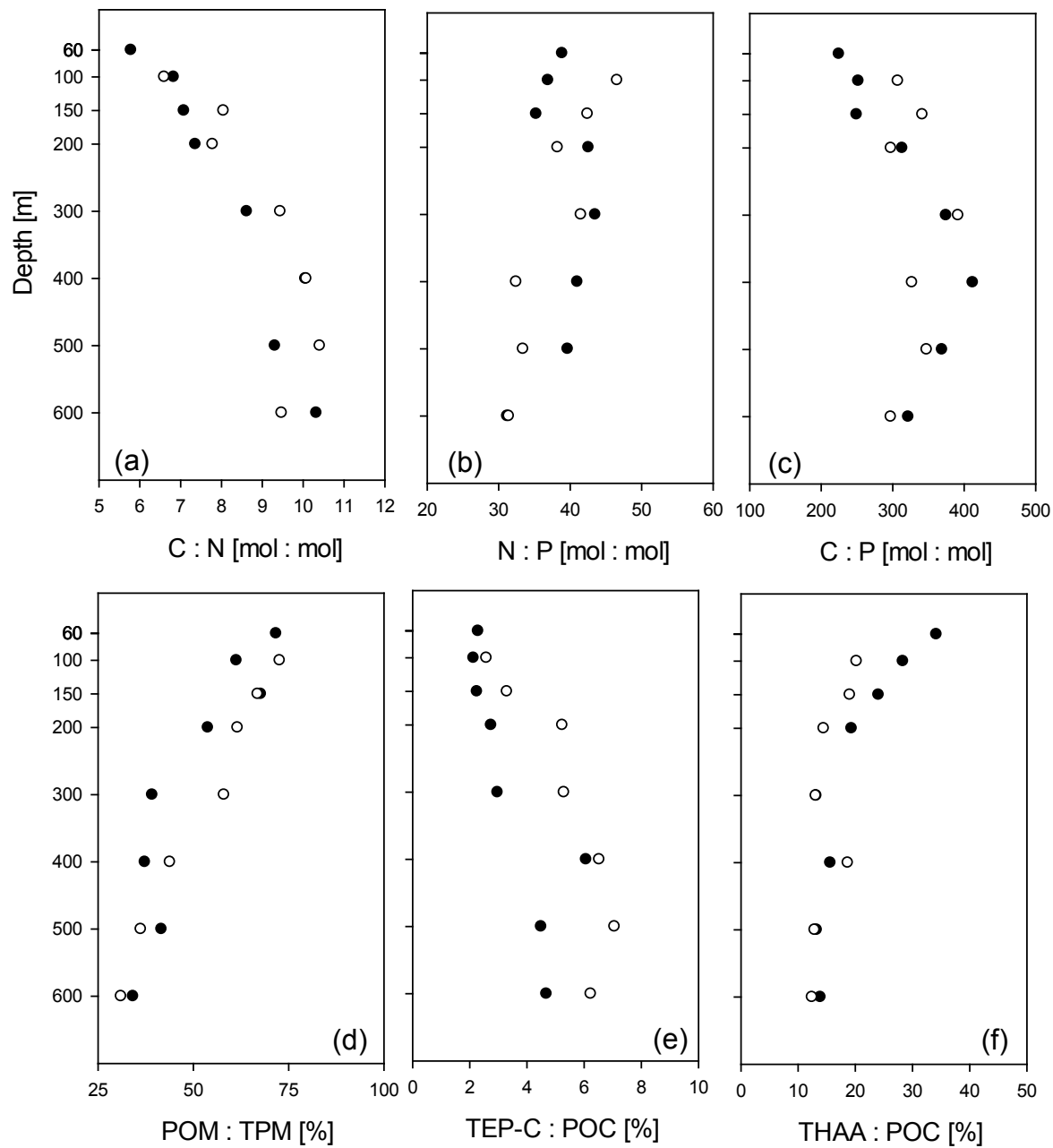

Figure 5. Changes in organic matter composition of particles sinking through the OMZ during the deployment of two STDT in the ETNA. Solid symbols are used for deployment no. 1 and open symbols for deployment no. 2.

conditions (Bar-Zeev and Rahav, 2015). One possible explanation for increasing [TEP-C]: [POC] in the hypoxic OMZ of the ETNA region could be that TEP are mostly included in sinking aggregates, whereas POC could be included in various particle types, such as large cells, detritus or fecal pellets. Ploug et al. (1997) estimated that carbon turnover time inside anoxic aggregates can be strongly reduced. Due to high microbial activity and reduced water, exchange aggregates sinking into hypoxic waters are more likely to experience anoxic conditions than individual particles (Ploug and Bergkvist, 2015). Thus, TEP settling into hypoxic waters by aggregates may be exposed to anoxia, and therewith to reduced microbial degradation, in consequence leading to a preferential TEP transfer through the OMZ. This may also explain the decrease of [TEP-C]: [POC] ratios below the $\mathrm{OMZ}$ at $600 \mathrm{~m}$ water depth, which was, however, only observed during the second deployment. Since PN was more rapidly degraded than $\mathrm{POC}$ this also implied that the ratio of $[\mathrm{PN}]$ : [TEP-C] became lower with depth.
In contrast to [TEP-C]:[POC], values of [PHAA$\mathrm{C}]$ : [POC] in POM fluxes declined during both deployments above the OMZ. However, within the core of the OMZ, at $400 \mathrm{~m}$, [PHAA-C] : [POC] was higher than at 300 and $500 \mathrm{~m}$ (Fig. 5f); the same pattern was also observed for [PHAA$\mathrm{N}]$ : [PN] (data not shown). A faster decline in PHAA in sinking particles mainly above but not within the OMZ is different to observations gained for more extensively oxygendeficient to full anoxic waters of the eastern tropical South Pacific (ETSP), which suggested that PHAAs are preferentially degraded under low-oxygen conditions (Van Mooy et al., 2002). In those studies, total hydrolyzable amino acid (THAA) degradation under anoxic conditions was found to continue with the same rate compared to oxic conditions, while degradation of non-amino acid compounds was found to slow down (Pantoja et al., 2004; Van Mooy et al., 2002). A preferential degradation of $\mathrm{N}$-rich compounds over POC suggests that microbes degrading organic matter under strongly oxygen-deficient conditions via denitrification preferentially 
Table 2. Composition (\% Mol) and degradation index (DI) of PHAA collected at different depths during two trap deployments (1 and 2) in the ETNA region.

\begin{tabular}{lcccccccccccccc}
\hline Depth $(\mathrm{m})$ & AsX & GlX & Ser & Gly & Thr & Arg & Ala & GABA & Tyr & Val & Iso & Phe & Leu & DI \\
\hline & & & & & & Deployment 1 & & & & & \\
\hline 60 & 13.89 & 14.69 & 8.36 & 12.94 & 7.57 & 5.89 & 12.26 & 0.21 & 0.02 & 6.13 & 5.12 & 4.05 & 8.86 & 0.34 \\
100 & 13.48 & 14.23 & 8.46 & 14.12 & 7.56 & 5.68 & 12.55 & 0.22 & 0.00 & 6.21 & 5.01 & 3.85 & 8.62 & 0.23 \\
150 & 13.80 & 13.90 & 9.10 & 14.27 & 7.20 & 6.12 & 11.57 & 0.27 & 0.04 & 6.19 & 5.07 & 3.97 & 8.49 & 0.29 \\
200 & 14.58 & 14.63 & 8.35 & 15.16 & 7.75 & 5.56 & 11.75 & 0.26 & 0.14 & 5.62 & 4.51 & 3.82 & 7.88 & 0.07 \\
300 & 14.06 & 13.01 & 8.72 & 16.45 & 7.99 & 5.55 & 11.74 & 0.44 & 0.79 & 5.54 & 4.33 & 3.77 & 7.59 & 0.03 \\
400 & 14.08 & 12.90 & 8.75 & 16.48 & 7.59 & 5.69 & 11.81 & 0.37 & 0.30 & 5.94 & 4.62 & 3.80 & 7.66 & 0.02 \\
500 & 13.62 & 12.55 & 9.16 & 17.02 & 7.95 & 5.75 & 11.23 & 0.42 & 0.38 & 5.87 & 4.61 & 3.88 & 7.55 & 0.02 \\
600 & 13.55 & 12.29 & 8.96 & 17.57 & 7.63 & 5.63 & 11.40 & 0.46 & 1.09 & 5.88 & 4.47 & 3.71 & 7.36 & 0.07 \\
\hline & & & & & & Deployment 2 & & & & & \\
\hline 100 & 14.15 & 13.94 & 8.46 & 14.29 & 7.76 & 5.90 & 11.94 & 0.22 & 0.84 & 5.69 & 4.57 & 4.00 & 8.26 & 0.24 \\
150 & 13.95 & 13.53 & 8.29 & 14.65 & 7.87 & 5.77 & 11.57 & 0.19 & 1.64 & 5.66 & 4.56 & 4.07 & 8.24 & 0.37 \\
200 & 14.19 & 12.73 & 8.54 & 15.93 & 8.10 & 5.78 & 11.42 & 0.31 & 0.96 & 5.68 & 4.44 & 4.05 & 7.87 & 0.13 \\
300 & 14.17 & 12.05 & 9.29 & 16.02 & 8.05 & 5.61 & 11.69 & 0.49 & 1.10 & 5.65 & 4.30 & 4.04 & 7.54 & 0.07 \\
400 & 13.19 & 11.75 & 8.58 & 17.71 & 7.98 & 5.31 & 12.10 & 0.37 & 1.82 & 5.77 & 4.15 & 3.83 & 7.43 & 0.08 \\
500 & 14.15 & 11.77 & 9.03 & 18.54 & 7.94 & 5.72 & 10.85 & 0.46 & 1.25 & 5.58 & 3.93 & 3.80 & 6.97 & -0.09 \\
600 & 14.06 & 11.89 & 9.55 & 18.70 & 7.18 & 6.01 & 11.02 & 0.55 & 1.29 & 5.19 & 3.86 & 3.65 & 7.05 & -0.04 \\
\hline
\end{tabular}

utilize nitrogen-rich amino acids (Van Mooy et al., 2002). Our data on PHAA do not suggest preferential amino acid loss due to components of sinking POM degradation in the ETNA OMZ. This is in accordance with the absence of microbial N-loss processes and absence of denitrifying bacteria in ETNA oxygen-deficient waters (Löscher et al., 2016). Instead, a slight increase of [PHAA-C]: [POC] in the OMZ may point to higher protein production by bacterial growth as previously observed for mesopelagic waters (Lee and Cronin, 1982, 1984) and may be related to increased growth efficiency of bacteria experiencing low-oxygen condition as suggested by Keil et al. (2016).

Among all amino acids determined, GIX, Gly, GABA and Leu showed the most pronounced variations with depth (Fig. 6a-d, Table 2). Whereas GIX and Leu decreased with depth (Fig. 6a, c), Gly continuously increased. It has been shown that Gly is enriched in the silica-protein complex of diatom frustules (Hecky et al., 1973). Preservation of frustules relative to POM may therefore explain the relative increase of Gly with depth in sinking particles. GIX has been used as a biomarker (Abramson et al., 2010), since GlX was shown to be enriched in calcareous plankton (Weiner and Erez, 1984). During this study \%Mol of GIX was higher during the first deployment, which is in accordance with the observed higher contribution of $\left[\mathrm{CaCO}_{3}+\right.$ lith] to TPM flux. GABA has been used as an indicator for bacterial decomposition activity (Lee and Cronin, 1982; Dauwe and Middelburg, 1998; Engel et al., 2009). During this study \%Mol GABA behaved differently during the first compared to the second deployment with similar values within the OMZ, a pattern also observed for opal fluxes (Fig. 3b). Moreover, \% Mol of
GABA showed a local peak at $300 \mathrm{~m}$, i.e., within the upper oxycline, and may point to high bacterial activity at this depth. Leu is an essential amino acids and readily taken up by heterotrophic microorganisms. Little change in \%Leu in the OMZ core (Fig. 3d) compared to above $(<300 \mathrm{~m})$ indicated reduced microbial reworking of organic matter under hypoxic conditions. Another indication of microbial reworking of organic matter can be derived from the degradation index (Dauwe et al., 1999). During this study, the DI decreased with increasing depth, but with differences between the deployments (Fig. 7). During no. 2, DI was slightly higher above the OMZ, indicating fresher material. During no. 1, the DI did not decrease within the OMZ, but it continued to decrease from 300 to $500 \mathrm{~m}$ depth during no. 2 . Together with observations on Chl $a$ and opal fluxes, as well as changes in ballast ratio, data on DI suggest that the particles of more diatomaceous origin likely continued to decompose under hypoxic conditions.

\section{Conclusions}

Despite an improvement in our understanding of the principle processes and drivers of particle export processes over the past decades, spatial and temporal variability of export fluxes in the ocean is still difficult to predict. This is partly due to the lack of observations in different regions of the mesopelagic realm. Our study is the first to describe fluxes of POM in the hypoxic mesopelagic waters of the ETNA. Our data suggest a higher transfer efficiency than expected from seawater temperature solely, suggesting reduced degradation 

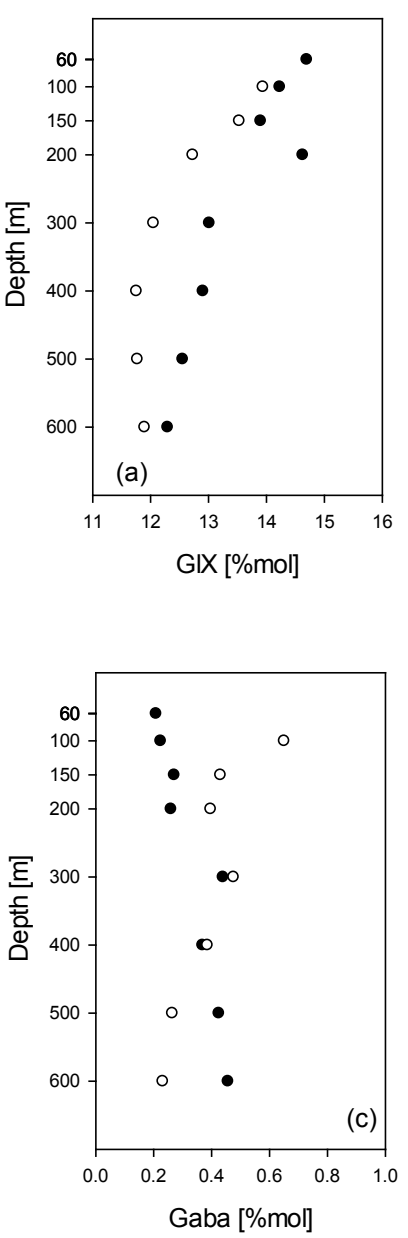
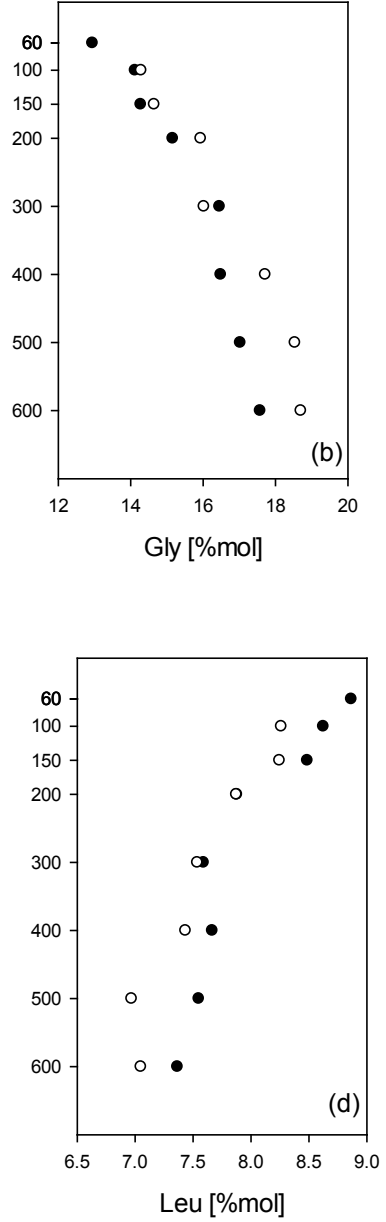

Figure 6. Molar percentages of selected amino acids contained in PHAA during the deployment of two STDT in the ETNA. Solid symbols are used for deployment no. 1 and open symbols for deployment no. 2 .

of organic matter by heterotrophic communities at low oxygen concentration $\left(<60 \mu \mathrm{mol} \mathrm{O} \mathrm{O}_{2} \mathrm{~kg}^{-1}\right)$. The biological carbon pump in high-productivity regimes associated to OMZs, i.e., eastern boundary upwelling systems such as the ETNA region off Mauritania, may therewith be more efficient than in fully oxygenated waters of comparable temperature. In contrast to suboxic systems $\left(<5 \mu \mathrm{mol} \mathrm{O}_{2} \mathrm{~kg}^{-1}\right)$ a relatively higher loss of amino acids from POM fluxes was not evident for the hypoxic water column, suggesting microbial $\mathrm{N}$-loss processes were comparatively minor within particles. This, however, requires further investigation since no corresponding rate measurements of denitrification or anammox were conducted during this study. Organic matter composition seems to have a large impact on $T_{\text {eff }}$ as carbon fluxes associated to amino acids were much more attenuated over depth than carbon fluxes associated to polysaccharide-rich TEP. If these findings are transferable to other oceanic regions, changes in surface ocean organic matter composition

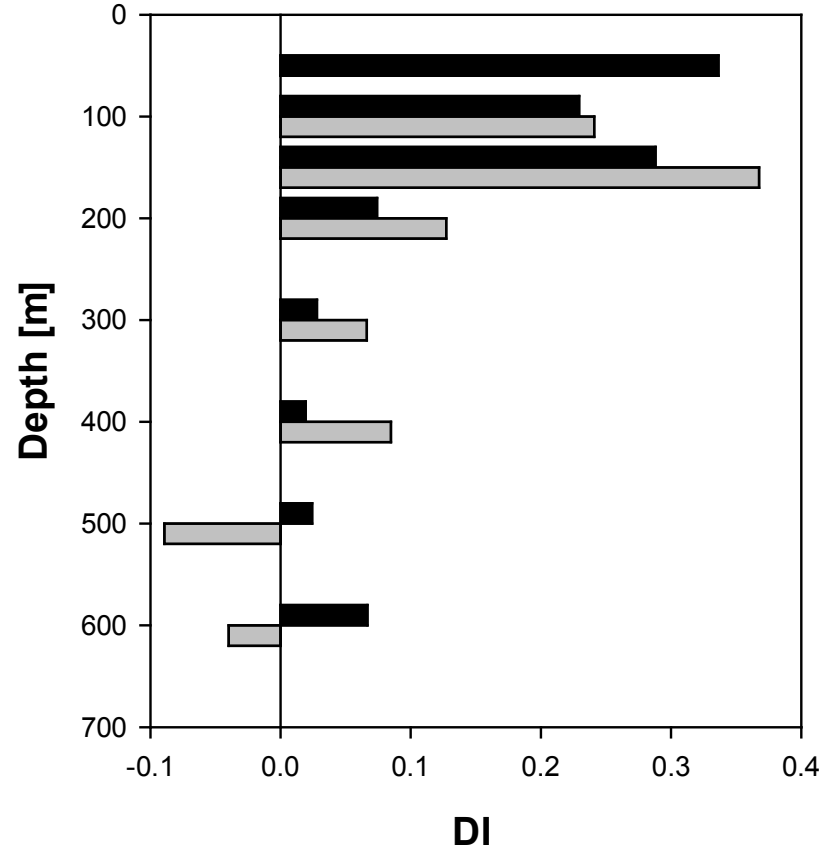

Figure 7. Degradation index (DI) of organic matter in trap-collected sinking particles based on amino acid composition and calculated according to Dauwe et al. (1999). Black bars are used for deployment no. 1 and gray bars for deployment no. 2 .

in response to climate change may also impact the carbon remineralization depth and therewith may have a feedback potential to atmospheric $\mathrm{CO}_{2}$ concentration that has yet to be assessed.

Data availability. All data will become available at https://doi. pangaea.de/10.1594/PANGAEA.874268 upon publication.

Competing interests. The authors declare that they have no conflict of interest.

Acknowledgements. This study is a contribution to the Collaborative Research Center 754/SFB Sonderforschungsbereich 754 "Climate-Biogeochemistry Interactions in the Tropical Ocean". We thank Martin Visbeck, Toste Tanhua, Tobias Hahn, Sunke Schmidtko and Gerd Krahmann for scientific and technical support as well as for providing oxygen and CTD data. Many thanks go to the shipboard scientific party and crew of Meteor cruise M105. Jon Roa, Ruth Flerus, Scarlett Sett and Tania Klüver are acknowledged for technical assistance. We thank Cindy Lee (Stony Brook University) for helpful advices. FACLM is supported by the DFG Excellence cluster Future Ocean. All data will become available at www.pangea.de upon publication.

Edited by: G. Herndl

Reviewed by: two anonymous referees 


\section{References}

Abramson, L., Lee, C., Liu, Z. F., Wakeham, S. G., and Szlosek, J.: Exchange between suspended and sinking particles in the northwest Mediterranean as inferred from the organic composition of in situ pump and sediment trap samples, Limnol. Oceanogr., 55, 725-739, doi:10.4319/lo.2009.55.2.0725, 2010.

Alldredge, A. L. and Cohen, Y.: Can microscale chemical patches persist in the sea? Microelectrode study of marine snow, fecal pellets, Science, 235, 689-691, 1987.

Alldredge, A. L. and Gotschalk, C. C.: Direct observation of the mass flocculation of diatom blooms: characteristics, settling velocities and formation of diatom aggregates, Deep-Sea Res., 36, 159-171, 1989.

Alldredge, A. L., Passow, U., and Logan, B. E.: The abundance and significance of a class of large, transparent organic particles in the ocean, Deep-Sea Res., 40, 1131-1140, 1993.

Arrigo, K. R.: Carbon cycle - Marine manipulations, Nature, 450, 491-492, 2007.

Azetsu-Scott, K. and Passow, U.: Ascending marine particles: Significance of transparent exopolymer particles (TEP) in the upper ocean, Limnol. Oceanogr., 49, 741-748, 2004.

Bar-Zeev, E. and Rahav, E.: Microbial metabolism of transparent exopolymer particles during the summer months along a eutrophic estuary system, Front. Microbiol., 6, 403, doi:10.3389/fmicb.2015.00403, 2015.

Belcher, A., Iversen, M., Manno, C., Henson, S. A., Tarling, G. A., and Sanders, R.: The role of particle associated microbes in remineralization of fecal pellets in the upper mesopelagic of the Scotia Sea, Antarctica, Limnol. Oceanogr., 61, 1049-1064, doi:10.1002/lno.10269, 2016

Bishop, J. K. B., Ketten, D. K., and Edmon, J. M.: The chemistry, biology and vertical flux of particulate organic matter from the upper $400 \mathrm{~m}$ of the Cape Basin in the southeast Atlantic Ocean, Deep-Sea Res., 25, 1121-1161, 1978.

Buesseler, K. O.: The decoupling of production and particulate export in the surface ocean, Global Biogeochem. Cy., 12, 297-310, 1998.

Buesseler, K. O. and Boyd, P. W.: Shedding light on processes that control particle export and flux attenuation in the twilight zone, Limnol. Oceanogr., 54, 1210-1232, 2009.

Buesseler, K. O., Lamborg, C. H., Boyd, P. W., Lam, P. J., Trull, T. W., Bidigare, R. R., Bishop, J. K. B., Casciotti, K. L., Dehairs, F., Elskens, M., Honda, M., Karl, D. M., Siegel, D. A., Silver, M. W., Steinberg, D. K., Valdes, J., Van Mooy, B., and Wilson, S.: Revisiting carbon flux through the ocean's twilight zone, Science, 316, 567-570, 2007a.

Buesseler, K. O., Antia, A., Chen, M., Fowler, S. W., Gardner, W.D., Gustafsson, O., Harada, K., Michaels, A. F., van der Loeff, M. R., Sarin, M., Steinberg, D. K., and Trull, T.: An assessment of the use of sediment traps for estimating upper ocean particle fluxes, J. Mar. Res., 65, 345-416, $2007 b$.

Cavan, E. L., Le Moigne, F. A. C., Poulton, A. J., Tarling, G. A., Ward, P., Daniels, C. J., Fragoso, G. M., and Sanders, R. J.: Attenuation of particulate organic carbon flux in the Scotia Sea, Southern Ocean, is controlled by zooplankton fecal pellets, Geophys. Res. Lett., 42, 821-830, doi:10.1002/2014GL062744, 2015

Chow, J. S., Lee, C., and Engel, A.: The influence of extracellular polysaccharides, growth rate, and free coccoliths on the coagu- lation efficiency of Emiliania huxleyi, Mar. Chem., 175, 5-17, 2015.

Dauwe, B. and Middelburg, J. J.: Amino acids and hexosamines as indicators of organic matter degradation state in North Sea sediments, Limnol. Oceanogr., 43, 782-798, 1998.

Dauwe, B., Middelburg, J. J., Herman, P. M. J., and Heip, C. H. R.: Linking diagenetic alteration of amino acids and bulk organic matter reactivity, Limnol. Oceanogr., 44, 1809-1814, 1999.

Devol, A. H. and Hartnett, H. E.: Role of the oxygen minimum zone in transfer of organic carbon to the deep ocean, Limnol. Oceanogr., 25, 1684-1690, 2001.

Dittmar, T., Cherrier, J., and Ludwichowski, K.-U.: The Analysis of Amino Acids in Seawater, in: Practical Guidelines for the Analysis of Seawater, CRC Press, 2009.

Ebersbach, F., Assmy, P., and Martin, P., Schulz, I, Wolzenburg, S., and Nöthig, E. M.: Particle flux characterisation and sedimentation patterns of protistan plankton during the iron fertilisation experiment LOHAFEX in the Southern Ocean, Deep-Sea Res. Pt. I, 89, 94-103, 2014.

Engel, A.: The role of transparent exopolymer particles (TEP) in the increase in apparent particle stickiness (alpha) during the decline of a diatom bloom, J. Plankton Res., 22, 485-497, 2000.

Engel, A.: Distribution of transparent exopolymer particles (TEP) in the northeast Atlantic Ocean and their potential significance for aggregation processes, Deep-Sea Res. Pt. I, 51, 83-92, 2004.

Engel, A.: Determination of Marine Gel Particles, in: Practical Guidelines for the Analysis of Seawater, edited, CRC Press, 2009.

Engel, A., Thoms, S., Riebesell, U., Rochelle-Newall, E., and Zondervan, I.: Polysaccharide aggregation as a potential sink of marine dissolved organic carbon, Nature, 428, 929-932, 2004.

Engel, A., Abramson, L., Szlosek, J., Liu, Z., Stewart, G., Hirschberg, D., and Lee, C.: Investigating the effect of ballasting by $\mathrm{CaCO}_{3}$ in Emiliania huxleyi, II: Decomposition of particulate organic matter, Deep-Sea Res. Pt. II, 56, 1408-1419, 2009.

Engel, A., Piontek, J., Grossart, H. P., Riebesell, U., Schulz, K. G., and Sperling, M.: Impact of $\mathrm{CO}_{2}$ enrichment on organic matter dynamics during nutrient induced coastal phytoplankton blooms, J. Plankton Res., 36, 641-657, doi:10.1093/plankt/fbt125, 2014.

Giering, S. L. C., Sanders, R., Lampitt, R. S., Anderson, T. A.,Tamburini, C., Boutrif, M., Zubkov, M. V., Marsay, C. M., Henson, S. A., Saw, K., Cook, K., and Mayor, D. J.: Reconciliation of the carbon budget in the ocean's twilight zone, Nature, 507, 480-483, 2014.

Haake, B., Ittekkot, V., Ramaswamy, V., Nair, R. R., and Honjo, S. Fluxes of amino acids and hexosamines to the deep Arabian Sea, Mar. Chem., 40, 291-314, 1992.

Hansen, H. P. and Koroleff, F.: Determination of nutrients, in: Methods of seawater analysis, edited by: Grasshof, K., 159-228, 1999.

Hecky, R. E., Mopper, K., Kilham, P., and Degens, E. T.: Amino acid and sugar composition of diatom cell-walls, Mar. Biol., 19, 323-331, doi:10.1007/BF00348902, 1973.

Heinze, C., Meyer, S., Goris, N., Anderson, L., Steinfeldt, R., Chang, N., Le Quere, C., and Bakker, D. C. E.: The ocean carbon sink - impacts, vulnerabilities and challenges, Earth Syst. Dynam., 6, 327-358, doi:10.5194/esd-6-327-2015, 2015.

Iversen, M. H., Nowald, N., Ploug, H., Jackson, G. A., and Fischer, G.: High resolution profiles of vertical particulate organic matter export off Cape Blanc, Mauritania: Degradation 
processes and ballasting effects, Deep-Sea Res., 57, 771-784, doi:10.1016/j.dsr.2010.03.007, 2010.

Keil, R. G., Neibauer, J. A., Biladeau, C., van der Elst, K., and Devol, A. H.: A multiproxy approach to understanding the "enhanced" flux of organic matter through the oxygen-deficient waters of the Arabian Sea, Biogeosciences, 13, 2077-2092, doi:10.5194/bg-13-2077-2016, 2016.

Klaas, C. and Archer, D. E.: Association of sinking organic matter with various types of mineral ballast in the deep sea: Implications for the rain ratio, Global Biogeochem. Cy., 16, 1116, doi:10.1029/2001GB001765, 2002.

Knauer, G. A., Martin, J. H., and Bruland, K. W.: Fluxes of particulate carbon, nitrogen, and phosphorus in the upper water column of the northeast Pacific, Deep-Sea Res., 26, 97-108, 1979.

Kohlfeld, K. E. and Ridgewell, A. Glacial-Interglacial Variability in Atmospheric $\mathrm{CO}_{2}$, in: Surface Ocean-Lower Atmosphere Processes Geophysical Research Series, American Geophysical Union, 187, 251-286, doi:10.1029/2008GM000845, 2009.

Kwon, E. Y., Primeau, F., and Sarmiento J. L.: The impact of remineralization on the air-sea carbon balance, Nat. Geosci., 2, 630 635, doi:10.1038/ngeo612, 2009.

Lam, P. J, Doney, S. C., and Bishop J. K. B.: The dynamic ocean biological pump: Insights from a global compilation of particulate organic carbon, $\mathrm{CaCO}_{3}$ and opal concentrations profiles from the mesopelagic, Global Biogeochem. Cy., 25, GB3009, doi:10.1029/2010GB003868, 2011.

Lampitt, R. S., Noji, T., and Von Bodungen, B.: What happens to zooplankton fecal pellets-implications for material flux, Mar. Biol., 104, 15-23, doi:10.1007/BF01313152, 1990.

Lee, C. and Cronin, C.: The vertical flux of particulate nitrogen in the sea: Decomposition of amino acids in the Peru upwelling area and the equatorial Atlantic, J. Mar. Res., 40, 227-251, 1982.

Lee, C. and Cronin, C., Particulate amino acids in the sea: Effects of primary productivity and biological decomposition, J. Mar. Res., 42, 1075-1097, 1984.

Le Moigne F., Sanders, R., Villa, M., Martin, A., Pabortsava, K., Planquette, H., Morris, P. J., and Thomalla, S.: On the proportion of ballast vs. non-ballast associated sinking POC in the surface ocean, Geophys. Res. Lett., 39, L15610, doi:10.1029/2012GL052980, 2012.

Lindroth, P. and Mopper, K.: High performance liquid chromatographic determination of subpicomole amounts of amino acids by precolumn fluorescence derivatization with ophthaldialdehyde, Anal. Chem., 51, 1667-1674, 1979.

Löscher, C. R., Bange, H. W., Schmitz, R. A., Callbeck, C. M., Engel, A., Hauss, H., Kanzow, T., Kiko, R., Lavik, G., Loginova, A., Melzner, F., Meyer, J., Neulinger, S. C., Pahlow, M., Riebesell, U., Schunck, H., Thomsen, S., and Wagner, H.: Water column biogeochemistry of oxygen minimum zones in the eastern tropical North Atlantic and eastern tropical South Pacific oceans, Biogeosciences, 13, 3585-3606, doi:10.5194/bg-13-3585-2016, 2016.

Mari, X.: Carbon content and $\mathrm{C}: \mathrm{N}$ ratio of transparent exopolymeric particles (TEP) produced by bubbling exudates of diatoms, Mar. Ecol. Progr. Ser., 183, 59-71, 1999.

Marsay, C. M., Sanders, R. J., Henson, S. S., Pabortsava, K., Achterberg, E. P., and Lampitt, R. S.: Attenuation of sinking particulate organic carbon flux through the mesopelagic ocean, P. Natl. Acad. Sci. USA, 112, 1089-1094, doi:10.1073/ pnas.1415311112, 2015.

Martin, P., Lampitt, R. S., Perry, M. J. Sanders, R. Lee, C., and D'Asaro, E.: Export and mesopelagic particle flux during a North Atlantic spring diatom bloom, Deep-Sea Res. Pt. I, 58, 338-349, 2011.

Martin, J. H., Knauer, G. A., Karl, D. M., and Broenkow, W. W.: Vertex - Carbon Cycling in the Northeast Pacific, Deep-Sea Res. A, 34, 267-285, doi:10.1016/0198-0149(87)90086-0, 1987.

Mortlock, R. A. and Froelich, P. N.: A simple method for the rapid determina- tion of biogenic opal in pelagic marine sediments, Deep-Sea Res. Pt. A, 36, 1415-1426, 1989.

Pantoja, S., Sepúlveda, J., and González, H. E.: Decomposition of sinking proteinaceous material during fall in the oxygen minimum zone off northern Chile, Deep-Sea Res. Pt. I, 51, 55-70, 2004.

Passow, U.: Transparent exopolymer particles (TEP) in aquatic environments, Prog. Oceanogr., 55, 287-333, 2002.

Passow, U., Shipe, R. F., Pak, D. K., Brzezinski, M. A., and Alldredge, A. L.: Origin of transparent exopolymer particles (TEP) and their role in the sedimentation of particulate matter, Cont. Shelf Res., 21, 327-346, 2000.

Ploug, H. and Bergkvist, J.: Oxygen diffusion limitation and ammonium production within sinking diatom aggregates under hypoxic and anoxic conditions, Mar. Chem., 176, 142-149, 2015.

Ploug, H., Kühl M., Buchholz-Cleven, B., and Jørgensen, B. B.: Anoxic aggregates - an ephemeral phenomenon in the pelagic environment?, Aquat. Microb. Ecol., 13, 285-294, 1997.

Schlitzer, R.: Ocean Data View, http://odv.awi.de, 2015.

Schneider, B., Engel, A., and Schlitzer, R.: Effects of depthand $\mathrm{CO}_{2}$-dependent $\mathrm{C}: \mathrm{N}$ ratios of particulate organic matter (POM) on the marine carbon cycle, Global Biogeochem. Cy., 18, GB2015, doi:10.1029/2003GB002184, 2004.

Soutar, A., Kling, S. A., Crill, P. A., Duffrin, E., and Bruland, K. W.: Monitoring the marine environment through sedimentation, Nature, 266, 136-139, 1977.

Stief, P., Kamp, A., Thamdrup, B., and Glud, R. N.: Anaerobic Nitrogen Turnover by Sinking Diatom Aggregates at Varying Ambient Oxygen Levels, Front. Micriobiol., 7, 98, doi:10.3389/fmicb.2016.00098, 2016.

Stramma, L., Johnson, G. C., Sprintall, J., and Mohrholz, V.: Expanding Oxygen-Minimum Zones in the Tropical Oceans, Science, 320, 655-658, 2008.

Suess, E.: Particulate organic carbon flux in the oceans - surface productivity and oxygen utilization, Nature, 288, 260-263, 1980.

Torres Valdez, S., Painter, C., Martin, A. P., Sanders, R., and Felden, J.: Data compilation of fluxes of sedimenting material from sediment traps in the Atlantic Ocean, Earth Syst. Sci. Data, 6, 123 145, doi:10.5194/essd-6-123-2014, 2014.

Van Mooy, B. A. S., Keil R. G., and Devol, A. H.: Impact of suboxia on sinking particulate organic carbon: Enhanced carbon flux and preferential degradation of amino acids via denitrification, Geochim. Cosmochim. Ac., 66, 457-465, doi:10.1016/s00167037(01)00787, 2002.

Visbeck M.: Oxygen in the Tropical Atlantic OSTRE Second Tracer Survey, Cruise, No. M105, 17 March-16 April 2014, Mindelo (Cape Verde), Mindelo (Cape Verde), METEORBerichte, M105, DFG-Senatskommission für Ozeanographie, 49 pp., doi:10.2312/cr_m105, 2014. 
Volk, T. and Hoffert, M. I.: Ocean carbon pumps: Analysis of relative strengths and efficiencies in ocean driven atmospheric $\mathrm{CO}_{2}$ changes, in: The Carbon Cycle and Atmospheric $\mathrm{CO}_{2}$ : Natural Variations Archean to Present, edited by: Sundquist, E. T. and Broecker, W. S., Geophysical Monograph Series, Washington, DC, American Geophysical Union, 32, 99-110, 1985.

Weiner, S. and Erez, J.: Organic matrix of the shell of the foraminifer Heterostegina depressa, J. Foramin. Res., 14, 206$212,1984$.
Welschmeyer, N. A.: Fluometric analysis of chlorophyll a in the resence of chlorophyll $b$ and pheopigments, Limnol. Oceanogr., 39, 1985-1992, 1994. 